\title{
Interventional Study on the Level of Awareness Pertaining to Thalassaemia among the Social Work College Freshmen in India
}

\author{
Arpita Patel \\ Research Scholar, Anand Institute of Social work, Anand, Sardar Patel University V.V. Nagar, Gujarat, India \\ Contact Details: Mobile: 8153065629 \\ Email id: arpitapatel2736[at]gmail.com
}

\begin{abstract}
Thalassaemia is a hereditary disorder that results in reduced production of haemoglobin. Statistics reveal that in India thalassaemia major affects over 1, 00,000 people and over 8,000 reported thalassaemia births take place every year. There are, however, many more unreported cases as well. Control of thalassaemia in India is a major problem due to ignorance about the disease, social, cultural and religious taboos and family influences. This study was conducted to assess the knowledge among the social work college freshman. A descriptive action research carried out in Anand Institute of Social Work, Anand, in Gujarat, India in September 2017. After intervention almost $100 \%$ study population gained knowledge related to thalassaemia and its importance.
\end{abstract}

Keywords: Thalassaemia, Knowledge, disorder

\section{Introduction}

Thalassaemia is one of the most common inherited gene disorders in India. ${ }^{[1]}$ Thalassaemia is a genetic blood disorder in which a patient cannot make enough Red Blood Cells and needs to be supplemented with RBC transfusions every 2-3 weeks to stay healthy and to survive. ${ }^{[2]}$ Thalassaemia is a serious disease causing severe anaemia, ineffective erythropoiesis, extramedullary hematopoiesis, and iron overload resulting from transfusion and increased iron absorption. ${ }^{[3,4]}$ The common signs and symptoms of thalassaemic diseases include pale skin, retarded growth \& puberty, anaemia, enlarged spleen, and increased susceptibility to infections. ${ }^{[5]}$ Worldwide, approximately 15 million people are estimated to suffer from thalassaemic disorders. About 240 million carriers of $\beta$ - thalassaemia worldwide, i.e. $1.5 \%$ of world population, and in India alone, the number is approximately 30 million with 505 in South East Asia. The burden of hemoglobinopathies in India is very high with nearly 12,000 infants being born every year with a severe disorder. These numbers imply that in every hour 1 child is born who will suffer with this genetic disorder. The carrier rate for $\beta$ - thalassaemia varies from 1-17 \% in India with an average of $3.2 \%$. This means that on an average 1 in every 25 Indians is a carrier of thalassaemia. ${ }^{[6]}$

The most common treatment for all major forms of thalassaemia is red blood cell transfusions. These transfusions are very much important to provide the patient with a temporary supply of healthy red blood cells with normal haemoglobin capable of carrying the oxygen that the patient's body demands. Today, most of the patients with thalassaemia major receive red blood cell transfusions every two to three weeks. Chelation therapy is another common treatment as by this excessive iron is removed from the body as the patient undergoes the difficult and painful infusion of a drug named Desferal. However, bone marrow transplantation or gene therapy may totally cure a case of thalassaemia major; as this therapy is very expensive rare one can afford it. But for all practical purposes transfusion of red cell concentrate in the only path to sustain the life of a thalassaemia patient at present. [7] The best way to reduce the burden of thalassaemia is prevention. However, the quality of life of children with thalassaemia should be improved. There are different strategies to prevent thalassaemia, which include parental awareness, population screening, genetic counselling, and prenatal diagnosis. Creating awareness and educating parents as well as youth proved to be cost-effective in the prevention of the disease and improvement of quality of life of patients with thalassaemia. ${ }^{[8,9]}$

\section{Objectives}

1.To assessing the level of awareness pertaining to thalassaemia among the social work college freshmen.

\section{Methodology}

The study was conducted at Shri Ramkrishna Seva Mandal managed Anand Institute of Social Work, Anand, Gujarat in 2017. The respondents of this study were newly enrolled undergraduate students of social work. The data was collected using a structured interview schedule prepared by researcher. Researcher was applied simple random sampling method for the data collection and type of research was descriptive action research. Collected data analysed using descriptive statistics and presented in frequency and percentage.

\section{Discussion}

A total of 19 students were consented to participate in the study. Regarding the personal information of the study population, it was seen that out of total 19 study populations, $11(57.9 \%)$ were males; while $8(42.1 \%)$ 


\section{International Journal of Science and Research (IJSR) \\ ISSN (Online): 2319-7064}

Index Copernicus Value (2016): 79.57 | Impact Factor (2015): 6.391

were females. In the present study more than half (78.9\%) participants were Hindu.

Table 1 demonstrated pre and post primary awareness of thalassaemia among the freshman of social work with the use of audio visual aid intervention. Before intervening it was found that out of 19 study population, 11 (57.9\%) were not aware about thalassaemia. After using audio visual aid all, $19(100 \%)$ were aware. After intervening in response to the question about whether thalassaemia an inherited disorder or not, $84.2 \%$ of the present study population answered correctly. About prenatal diagnosis $100 \%$ population were aware about the same. In the present study, commonest source of information about thalassaemia was from other sources i.e. documentary related to thalassaemia awareness prepared by Indian Red Cross Society. As the study population was freshman of social work in pre analysis $100 \%$ had not gone through screening of thalassaemia, but with the help of Indian red cross society, (Anand Branch) all 100\% had gone through screening. Almost 100\% agreed that premarital screening can prevent thalassaemia.

Table 2 and Table 3 revealed knowledge pertaining to causes and treatments of thalassaemia. About 52.6\% knew that both parents have to be carriers of beta thalassaemia to have an affected child. Almost $100 \%$ agreed that thalassaemia major is not curable and caused because of allergy. In the present study about $57.9 \%$ population knew that blood transfusion is prime treatment of thalassaemia major. As blood transfusion is one of the treatment of thalassaemia major about $42.1 \%$ populations were agreed on it is very expensive. About side effects of this treatment $26.3 \%$ answered liver failure where as $21.1 \%$ replied skin rashes. In thalassaemia, there is increased risk of iron overload due to regular transfusion so that $84.2 \%$ replied correctly on iron containing food is not healthy for thalassaemic major.

Table 1: Showing information related to primary awareness about thalassaemia

$(\mathrm{N}=19)$

\begin{tabular}{|c|c|c|c|c|}
\hline \multirow{2}{*}{$\begin{array}{c}\text { Information pertaining to } \\
\text { awareness about thalassaemia }\end{array}$} & \multicolumn{2}{|c|}{ Pre } & \multicolumn{2}{|c|}{ Post } \\
\hline & Frequency & Percentage (\%) & Frequency & Percentage $(\%)$ \\
\hline \multicolumn{5}{|c|}{ Information about thalassaemia } \\
\hline Yes & 8 & $42.1 \%$ & 19 & $100 \%$ \\
\hline No & 11 & $57.9 \%$ & 0 & $0.00 \%$ \\
\hline \multicolumn{5}{|c|}{ Source of Information } \\
\hline Newspaper & 1 & $5.3 \%$ & 0 & $0.00 \%$ \\
\hline TV & 1 & $5.3 \%$ & 0 & $0.00 \%$ \\
\hline Voluntary Organisation & 1 & $5.3 \%$ & 0 & $0.00 \%$ \\
\hline Other & 5 & $26.3 \%$ & 19 & $100 \%$ \\
\hline Not applicable & 11 & $57.9 \%$ & 0 & $0.00 \%$ \\
\hline \multicolumn{5}{|c|}{ Disease of the blood } \\
\hline Yes & 5 & $26.3 \%$ & 18 & $94.7 \%$ \\
\hline No & 1 & $5.3 \%$ & 1 & $5.3 \%$ \\
\hline Don't know & 13 & $68.4 \%$ & 0 & $0.00 \%$ \\
\hline \multicolumn{5}{|c|}{ Inherited disorder } \\
\hline Yes & 4 & $21.1 \%$ & 16 & $84.2 \%$ \\
\hline No & 2 & $10.5 \%$ & 3 & $15.8 \%$ \\
\hline Don't know & 13 & $68.4 \%$ & 0 & $0.00 \%$ \\
\hline \multicolumn{5}{|c|}{ Passing through gene } \\
\hline Yes & 6 & $31.6 \%$ & 17 & $89.5 \%$ \\
\hline No & 1 & $5.3 \%$ & 0 & $0.00 \%$ \\
\hline Don't know & 12 & $63.2 \%$ & 2 & $10.5 \%$ \\
\hline \multicolumn{5}{|c|}{ Detection during pregnancy } \\
\hline Yes & 1 & $5.3 \%$ & 19 & $100 \%$ \\
\hline No & 5 & $26.3 \%$ & 0 & $0.00 \%$ \\
\hline Don't know & 13 & $68.4 \%$ & 0 & $0.00 \%$ \\
\hline \multicolumn{5}{|c|}{ Thalassaemia screening before marriage } \\
\hline Yes & 0 & $0.00 \%$ & 19 & $100 \%$ \\
\hline No & 19 & $100 \%$ & 0 & $0.00 \%$ \\
\hline \multicolumn{5}{|c|}{ Importance of thalassaemia screening before marriage } \\
\hline Yes & 15 & $78.9 \%$ & 19 & $100.0 \%$ \\
\hline No & 4 & $21.1 \%$ & 0 & $0.00 \%$ \\
\hline \multicolumn{5}{|c|}{ Various beliefs regarding thalassaemia screening before marriage } \\
\hline Not necessary & 4 & $21.1 \%$ & 0 & $0.00 \%$ \\
\hline Not applicable & 15 & $78.9 \%$ & 19 & $100.0 \%$ \\
\hline
\end{tabular}

Volume 6 Issue 12, December 2017 www.ijsr.net 


\section{International Journal of Science and Research (IJSR) \\ ISSN (Online): 2319-7064}

Index Copernicus Value (2016): 79.57 | Impact Factor (2015): 6.391

Table 2: Showing information related to causes of thalassaemia $\mathrm{N}=19$

\begin{tabular}{|c|c|c|c|c|}
\hline \multirow{2}{*}{$\begin{array}{l}\text { Information pertaining to } \\
\text { causes about thalassaemia }\end{array}$} & \multicolumn{2}{|c|}{ Pre } & \multicolumn{2}{|c|}{ Post } \\
\hline & Frequency & Percentage (\%) & Frequency & Percentage (\%) \\
\hline \multicolumn{5}{|c|}{ Spread by food, medicine and infection } \\
\hline Yes & 1 & $5.3 \%$ & 0 & $0.00 \%$ \\
\hline No & 8 & $42.1 \%$ & 19 & $100 \%$ \\
\hline Don't know & 10 & $52.6 \%$ & 0 & $0.00 \%$ \\
\hline \multicolumn{5}{|c|}{ Higher risk of opportunistic infection } \\
\hline Yes & 4 & $21.1 \%$ & 15 & $78.9 \%$ \\
\hline No & 1 & $5.3 \%$ & 3 & $15.8 \%$ \\
\hline Don't know & 14 & $73.7 \%$ & 1 & $5.3 \%$ \\
\hline \multicolumn{5}{|c|}{ Communicable disease } \\
\hline Yes & 0 & $0.00 \%$ & 1 & $5.3 \%$ \\
\hline No & 3 & $15.8 \%$ & 16 & $84.2 \%$ \\
\hline Don't know & 16 & $84.2 \%$ & 2 & $10.5 \%$ \\
\hline \multicolumn{5}{|c|}{ Thalassaemia minor a disease } \\
\hline Yes & 1 & $5.3 \%$ & 1 & $5.3 \%$ \\
\hline No & 4 & $21.1 \%$ & 18 & $94.7 \%$ \\
\hline Don't know & 14 & $73.7 \%$ & 0 & $0.00 \%$ \\
\hline \multicolumn{5}{|c|}{ Brother and sister has thalassaemia minor } \\
\hline Yes & 1 & $5.3 \%$ & 5 & $26.3 \%$ \\
\hline No & 2 & $10.5 \%$ & 10 & $52.6 \%$ \\
\hline Don't know & 16 & $84.2 \%$ & 4 & $21.1 \%$ \\
\hline \multicolumn{5}{|c|}{ Thalassaemia major curable } \\
\hline Yes & 3 & $15.8 \%$ & 0 & $0.00 \%$ \\
\hline No & 1 & $5.3 \%$ & 19 & $100 \%$ \\
\hline Don't know & 15 & $78.9 \%$ & 0 & $0.00 \%$ \\
\hline \multicolumn{5}{|c|}{ Caused due to some allergy } \\
\hline No & 6 & $31.6 \%$ & 19 & $100 \%$ \\
\hline Don't know & 13 & $68.4 \%$ & 0 & $0.00 \%$ \\
\hline
\end{tabular}

Table 3: Showing information related to treatment of thalassaemia

$\mathrm{N}=19$

\begin{tabular}{|c|c|c|c|c|}
\hline \multirow{2}{*}{$\begin{array}{l}\text { Information pertaining to } \\
\text { treatment about thalassaemia }\end{array}$} & \multicolumn{2}{|c|}{ Pre } & \multicolumn{2}{|c|}{ Post } \\
\hline & Frequency & Percentage (\%) & Frequency & Percentage (\%) \\
\hline \multicolumn{5}{|c|}{ Iron containing food } \\
\hline Yes & 2 & $10.5 \%$ & 2 & $10.5 \%$ \\
\hline No & 2 & $10.5 \%$ & 16 & $84.2 \%$ \\
\hline Don't know & 15 & $78.9 \%$ & 1 & $5.3 \%$ \\
\hline \multicolumn{5}{|c|}{ Regular blood transfusion } \\
\hline Yes & 5 & $26.3 \%$ & 11 & $57.9 \%$ \\
\hline No & 6 & $31.6 \%$ & 8 & $42.1 \%$ \\
\hline Don't know & 8 & $42.1 \%$ & 0 & $0.00 \%$ \\
\hline \multicolumn{5}{|c|}{ Expenditure of the treatment } \\
\hline 1-3 lakhs & 6 & $31.6 \%$ & 0 & $0.00 \%$ \\
\hline 3-5 lakhs & 9 & $47.4 \%$ & 4 & $21.1 \mathrm{v}$ \\
\hline 5-7 lakhs & 4 & $21.1 \%$ & 8 & $42.1 \%$ \\
\hline 7-9 lakhs & 0 & $0.00 \%$ & 7 & $36.8 \%$ \\
\hline \multicolumn{5}{|c|}{ Side effects of the treatment } \\
\hline Yes & 6 & $31.6 \%$ & 13 & $68.4 \%$ \\
\hline No & 9 & $47.4 \%$ & 6 & $31.6 \%$ \\
\hline Don't know & 4 & $21.1 \%$ & 0 & $0.00 \%$ \\
\hline \multicolumn{5}{|c|}{ List of the side effects } \\
\hline Infection & 3 & $15.8 \%$ & 3 & $15.8 \%$ \\
\hline Heart Failure & 1 & $5.3 \%$ & 0 & $0.00 \%$ \\
\hline Fever & 1 & $5.3 \%$ & 0 & $0.00 \%$ \\
\hline Physical growth disorder & 1 & $5.3 \%$ & 0 & $0.00 \%$ \\
\hline Liver failure & 0 & $0.00 \%$ & 5 & $26.3 \%$ \\
\hline Skin rashes & 0 & $0.00 \%$ & 4 & $21.1 \%$ \\
\hline Swelling & 0 & $0.00 \%$ & 1 & $5.3 \%$ \\
\hline Not applicable & 13 & $68.4 \%$ & 6 & $31.6 \%$ \\
\hline
\end{tabular}

Volume 6 Issue 12, December 2017 www.ijsr.net

Licensed Under Creative Commons Attribution CC BY 


\section{Conclusion}

We conclude that awareness regarding thalassaemia is necessary among youth. Youth should be sensitized about the disease. There is a need for creating awareness among families with thalassaemia and the general public with the help of mass media, booklets, lectures, video, etc., so that the burden of thalassaemia in the community can be reduced and children with thalassaemia may have a better life. Besides, the Health Ministry can make the screening test for thalassaemia a compulsory for every newly enrolled freshman so that at least they know why they learn this type of blood disorder as well as significance of this type of awareness.

\section{References}

[1] Borgna-Pignatti C, Gamberini MR. Complications of thalassemia major and their treatment. Expert Rev Hematol 2011;4: 353-66.

[2] Ghosh, D. S., Help prevent thalassemia - Jago re, (2017, November 22). Retrieved from ww.hindujahospital.com:

https://www.hindujahospital.com/communityportal/art icles/articles-

details. . $5 x$ x cid $=5 \&$ cname $=$ Cardiology $\& i d=121 \&$ na me $=$ Latest $\% 20$ Articles

[3] Goyal, J., Hpapani, P. And Gagiya,h. (2015). Awareness among parents of children with thalassemia major from Western India. International Journal of Medical Science and Public Health, Vol 4 (10). Retrieved from https://pdfs.semanticscholar.org/26a2/101242cf251b2 2d386aad25f6c5bd66a78ac.pdf.

[4] IRCS, Blood Bank Intiation in Taking Care of the Thalassaemic patients (2017, November 22). Retrieved from www.indianredcross.org: http://www.indianredcross.org/press15.htm

[5] Mishra AK, Tiwari A. Iron overload in beta thalassaemia major and intermedia patients. Maedica (Buchar) 2013;8: 328-32.

[6] Mohanty D, Colah RB, Gorakshakar AC, Patel RZ, Master DC, Mahanta J, et al. Prevalence of $\beta$ thalassemia and other haemoglobinopathies in six cities in India: a multicentre study. J Community Genet 2013; 4:33-42.

[7] Tamhankar PM, Agarwal S, Arya V, Kumar R, Gupta UR, Agarwal SS. Prevention of homozygous beta thalassemia by premarital screening and prenatal diagnosis in India. Prenat Diagn 2009; 29:83-8. Erratum in: Prenat Diagn 2009;29:732.

[8] Thalassaemia India (2017, November 22). Retrieved from www.thalassemicsindia.org: http://www.thalassemicsindia.org/

[9] Vang P, Zongrum O, Sindhuphak R, Dusitsin N. Preliminary Study on Thalassemia Screening and Genetic Counseling in Selective Hmong People in Saraburi Province, Thailand. Hmong Studies Journal 2007; 8:1-19

Volume 6 Issue 12, December 2017 